\title{
6
}

\section{Challenges in waiting}

\author{
Why didst thou promise such a beauteous day, \\ And make me travel forth without my cloak, \\ To let base clouds o'ertake me in my way, \\ Hiding thy bravery in their rotten smoke? (Shakespeare) ${ }^{1}$
}

\section{Summary}

While the Russian economy under its new leader, Boris Yeltsin, began to slide in the early I990s as a result of an uncertain mix of change and standstill, economic reform in Central European transition countries started to bear fruit in the form of higher growth and adaptation to world markets. Military tensions diminished considerably with the ratification of the US-Russia START I Treaty reducing intercontinental nuclear missiles; the entry into force of the Conventional Forces in Europe (CFE) Treaty limiting troop levels all over Europe; and NATO's Partnership for Peace programme, also including Russia.

The European Union's Exchange Rate Mechanism (ERM) collapsed in 1993 but was revived in a more flexible form, permitting plans for Economic and Monetary Union (EMU) to proceed. The conclusion of the Uruguay Round and the establishment in 1995 of the World Trade Organisation meant a major push for Europe toward globalisation and its being exposed to greater competition from emerging non-European economies. Austria, Finland and Sweden joined the European Union in I995, increasing its membership to fifteen.

Other institutions, such as the Council of Europe, also included more and more members in Central, Eastern and South-Eastern Europe and began to form - with NATO, the European Union and the Organisation for Security and Co-operation in Europe (OSCE) - a rather complicated European 'security architecture'. All these organisations were faced with immediate challenges, such as successive wars in the former Yugoslavia and in the southern Russian province of Chechnya. The former led to 
the first 'out-of-area' NATO deployment of troops in Bosnia and Herzegovina, as a result of the 1995 Dayton Agreements.

\section{The post-Maastricht blues: recession and confusion}

In 1993 the world - and with it Europe - was in its first major recession since the early I980s. In I99I the recession had been delayed by Germany's major transfer of funds to the new Länder, leading to export gains for other European countries, especially in the West. However, by early 1993 the recession started to bite, as many Western European governments tried to reduce large public sector deficits and to contain inflation (not least to meet the still relatively distant, but approaching, European Monetary Union (EMU) convergence criteria).

The EU countries most committed to the EMU stuck to one of its key preparatory requirements, namely adherence to a maximum variation between each other's currencies of \pm 2.25 per cent. For the relatively weaker economies in the group - such as France and Belgium - staying within this band vis-à-vis the Deutschmark meant, however, having to raise interest rates to levels such that their economies suffered even more. In June 1993 the Exchange Rate Mechanism (ERM) collapsed - enriching speculators and impoverishing some central banks. However, it was revived after $\mathrm{a} \pm \mathrm{I} 5$ per cent widening of the currency bands had been introduced, reducing the scope for speculators but also taking away some of the seriousness of the ERM. (In the end it did, however, work rather well, as governments successfully stuck to fairly narrow fluctuations.)

Nobody seemed really sure any longer where Europe, or the world, was heading. On the one hand, Iraq's invasion of Kuwait had been repulsed and oil supplies were not in danger. On the other, however, Europeans knew, in their heart of hearts, that although they had fought alongside the Americans and other nations in this action, it would not have come about without US resolve in what was after all a crisis closer to Europe than to North America.

The economic slide in most Central and East European countries had given way to modest growth - with Poland, Hungary and the Czech Republic in the lead. However, even this growth was seen by some in Western Europe as reflecting a beginning industrial exodus from West to East. Would that East - so long neglected, and commiserated with because of its being on the 'wrong' side of the Iron Curtain - now rob the West of its wealth, until some distant future when both could prosper together? Would, in the meantime, immigration from the East add further to unemployment in the West? 
Events in Russia in the autumn of 1993 did nothing to soothe such fears. A long-simmering dispute between the reformist President Yeltsin and a conservative parliament came to a head in a 'second October revolution', lasting one day and ending with the (narrow) victory by the Yeltsin forces (supported by the military, the former KGB and the Ministry of the Interior) over angry demonstrators barricaded in an official building and shelled by army tanks.

If the forces of reform appeared to have won the day, the state of the Russian economy gave rise to concern. Gross domestic product (GDP) in I 993 fell by I 2 per cent compared to the year before, after an approximate 20 per cent drop in 1992 from the preceding year (although these falls also reflected the fact that the economy was undergoing reform away from a wasteful communist-era production pattern). Problems were everywhere: a budget deficit of Io per cent of GDP with continuing massive aid to state-owned industries; a monthly inflation rate of 20 per cent; slow privatisation of an agricultural sector whose situation was further aggravated by poor harvests; absent, confusing or conflicting legislation; and growing crime and corruption. All this added to the general feeling of uncertainty over the country's economic future. Foreign investors began to have cold feet, including the International Monetary Fund, which had made aid contingent on economic reform and stabilisation. It was clear that Russia had enormous potential, but when would domestic conditions permit that potential to be realised?

Russia's economic difficulties were upsetting to the rest of Europe. What would have happened if the forces of reaction had managed to oust the Yeltsin government? Would the new independence of the Baltic states have been in danger, together with that of states which many in Russia would now call the 'near abroad', i.e. the other successor republics to the Soviet Union? (The latter soon joined together in a loosely structured Community of Independent States as a result of Russian prodding.) Would Central and East European countries again have risked coming under Russian sway? Would economic reforms have been undone? Would the thousands of new private enterprises that had been formed have been forced into liquidation? Even with Yeltsin winning, would an economically distressed Russia become politically unpredictable?

Clearly the West, including the EU and other European organisations such as the Council of Europe, had a strong interest in trying to assist Russia in every way possible. Even so, a certain shift from financial to other types of assistance was taking place, and a certain weariness could be detected among donors as to the wisdom of continuing to fund a country with such uncertain prospects. 


\section{A new defence context}

There was no longer any serious military threat from Russia, at least not in the NATO area. Russian aircraft were rusting on abandoned airfields. Warships were being mothballed or scrapped. Morale in the formerly feared Soviet armed forces was low, because of lack of pay and worsening material conditions. The threat now was rather the accidental firing of a missile by a crazed unit in a Siberian silo or due to decay of the equipment, or the theft of a nuclear warhead or stored fission material by some rogue nation in, say, the Middle East. (In I 994 the United States actually paid for the removal of a large stock of bomb-grade plutonium from Russia to the United States.)

The threat of large-scale military conflict suddenly seemed remote. The I990 Conventional Forces in Europe (CFE) Treaty between the NATO and Warsaw Pact countries - begun already in the I980s with the Mutual and Balanced Force Reduction (MBFR) talks and painstakingly pursued through the highs and lows of the détente years became binding in November 1995. It obliged the thirty participating states to much lower force levels than before and to the elimination of 60 per cent of their heavy weapons.

Most countries were already moving to or going beyond these targets - a natural enough process when one considers that there was no longer any genuine East-West conflict. Why, indeed, should a country have large conventional forces when these cost money increasingly needed elsewhere, and when technological improvements added further advantage for the defender rather than the attacker? Put simply, why invest in a tank when it could be easily knocked out by an increasingly 'smart' anti-tank weapon?

In January I994 NATO invited all the former members of the Warsaw Pact and the successor states of the Soviet Union to join the organisation's Partnership for Peace (PfP) programme - allowing them to develop co-operative military relations with NATO, particularly in the area of joint planning and training for humanitarian and peacekeeping operations. By the end of 1994 Russia and all the other successor states to the Soviet Union except two (Belarus and Tajikistan) had joined the PfP, as had such countries as Finland, Slovenia and Sweden. The Western European Union also began to build up contacts with Central and Eastern Europe.

Finally, at world level, the US-Soviet Union START I Treaty entered into force in 1994 after nuclear weapons in Belarus, Kazakhstan and Ukraine were either destroyed or moved to Russia. Efforts to have the 
even more far-reaching START II ratified by both Russia and the United States were resumed. ${ }^{2}$ The sword of Damocles hanging over Europe (and the world) seemed to have been reduced in size, even if it had not disappeared altogether.

\section{A new trade context: the Uruguay Round and the World Trade Organisation}

In December I993 another event of importance to Europe occurred: the conclusion of seven years of negotiations for a new GATT round to govern future international relations in trade and investment. The signing of the Uruguay Round meant that the world's long march towards more and more open trade relations - started in 1947 with the setting up of the GATT - would continue for years if not decades to come.

World trade issues would henceforth be dealt with by a new WTO, rather than the more or less informal GATT. It would have more powers, particularly in the settling of disputes and in enforcement procedures. Moreover, the Uruguay Round was the first agreement to cover agriculture, textiles, intellectual property rights and certain services (even though some, such as telecommunications, shipping and audiovisual and financial services, were left out for want of an agreement). In this, the treaty went far beyond traditional issues of tariffs, quotas, dumping and countervailing duties, and into the traditionally domestic affairs of participating countries, such as competition laws and investment conditions.

The significance for Europe of the Uruguay Round, and the new World Trade Organisation to be created, was that the long process of an increasing 'division of labour' between the different regions of the world that had started with the GATT in the late r940s would continue. In the old days that division had been easy for Western Europe. The rich, industrialised countries produced the advanced products and services the world needed. The less developed countries continued to produce at a lower rung of the production ladder, and while they made inroads into some of the domains of richer countries, the latter made up for that by developing new domains. It was assumed that the richer countries would continue to give development assistance to the poorer ones with the aim of lifting them out of poverty. However, it was never imagined that this process might some day challenge the wealth or relative position of the wealthiest countries vis-à-vis the developing world.

The developing countries - at least those that did not become too dependent on foreign aid - saw it differently. In the I950s and I960s the emphasis had been on replacing industrial imports by domestic 
production and on exporting raw materials and agricultural commodities to the rich countries. This was the cardinal aim behind the United Nations Conference on Trade and Development formed in 1964, and behind the much-touted proposals for a New International Economic Order of the early I970s. (That ambition collapsed, since the forming of cartels among producing nations proved impossible in all but a handful of commodities. Even OPEC rapidly lost ground after its brief heyday in the I970s.)

Now, however, more and more developing countries began to concentrate on attracting subsidiaries of foreign multinationals and foreign direct investment generally. While developing countries used to fear free trade in advanced products and had been generally reluctant participants in earlier GATT rounds, they now became more and more eager proponents of open trade. (This did not, however, extend to intellectual property products, where many did not feel enthusiastic about paying royalties to, say, a US record company, a Michael Jackson, a Dior or a Chanel, especially if these could be made through 'underground' copycat factories at home.)

By the time of the signing of the Uruguay Round, an impressive number of 'emerging economies' in East and South-East Asia, Latin America and elsewhere had become major competitors with the 'old' industrialised countries. They had the advantage, from a trade competition point of view, of paying their workers much lower wages and providing little or no social protection (thus reducing extra-salary costs to employers). In some countries, child or prison labour was used. Although the workforce pool was large and labour was permanently added through migration from countryside to city, rising salaries in some of the countries had begun to drive out companies to poorer neighbours, finally engaging virtually the entire world in what had become known as the 'global economy'.

Again, this process was accelerated - indeed it could hardly have occurred - without the technological breakthrough symbolised by the microchip, making the transfer and sharing of information several orders of magnitude less expensive as well as instantaneous. Add to this an increased share of services in world commerce, cheaper and more efficient means of transport, and a shift toward higher value per weight unit in trade (giving air cargo a major share in overall transport), and the growing advantage of developing countries vis-à-vis the traditional industrialised countries in the trade arena becomes obvious.

Europe, which began to feel the effects of a number of closures of factories large and small across the whole industrial spectrum, had 
begun to take a more defensive stance in areas like agriculture, textiles, steel, coal and shipbuilding, while being more open-trade minded in areas like services and intellectual property. If at long last, after particularly bitter agricultural negotiations between the US and the EU, the Uruguay Round could be submitted for signature by the spring of I994 and set to enter into force by the beginning of 1995 , then this was largely because the two most important parties, the US and the EU, had been able to agree. Everybody at least believed that they had obtained a little more and sacrificed a little less than they would have done in the absence of the Round. However, everybody soon realised that the Uruguay Round Treaty, even at the time it was to enter into force, described the past rather than the present or future. A new treaty would be needed unless all matters could henceforth be dealt with on a continuous basis within the new World Trade Organisation.

Parallel to the worldwide framework for trade and investment provided by the Uruguay Round and the World Trade Organisation, a process of trade regionalisation was also under way. To the 'older' European Union and EFTA (and about a dozen other, less far-reaching trade arrangements in different parts of the world), would now have to be added the North American Free Trade Agreement (NAFTA) involving Canada, Mexico and the United States. In addition, a whole series of more extensive regional free-trade agreements were concluded: in Latin America (Mercosur, the Andean Pact, the Central American Common Market, the Caribbean Community and Common Market), in SouthEast Asia (Asian Free Trade Association) and in the Pacific rim including the United States and Canada (Asia-Pacific Economic Forum, or APEC). The tide was thus firmly in the direction of freer trade, the prime motor being technological change and foreign investment, mainly through multinational companies.

\section{Knocking on the EU's door: the Austrian, Finnish, Norwegian and Swedish candidatures}

The Treaty on European Union, commonly known as the Maastricht Treaty, entered into force in November I993. However, this was only after a second, this time positive, Danish referendum (and considerable concessions to Denmark by the other EU members); a year-long ratification battle in the British Parliament; and an extremely thorough and 'barely passed' examination by the German Federal Constitutional Court (following a citizens complaint that the treaty violated the country's constitution). 
In December I993 the so-called Schengen Agreement on free circulation of people came into force between nine EU member states (all except Denmark, Ireland and the UK), although France continued to have reservations owing to alleged Dutch liberalism with regard to its drugs policy. ${ }^{3}$ Furthermore, on I January 1994 the previously mentioned European Economic Area came into being, extending the essentials of the 'I992 project' of the Twelve to six of the seven EFTA states (all except Switzerland).

Hardly was the ink of that treaty dry, when it appeared that within a short time it would lose much of its significance through the expected EU membership of the four EFTA countries Austria, Finland, Norway and Sweden. (Switzerland had withdrawn its application following the negative referendum on the European Economic Area in December I992). Iceland had never applied, as it was wary of sharing its main resource, fish, under a common EU fisheries policy.

Why were the governments of the four EFTA candidates for EU membership not content with the European Economic Area? There were two main reasons. Firstly, the disappearance of the Soviet Union had swept away any apprehensions that Finland in particular, but also Sweden and Austria as neutral states, might have harboured about joining a Western political club such as the EU. Secondly, the EEA was essentially about the participating EFTA countries accepting existing and future EU legislation on even less than a 'take it or leave it' basis. If the Internal Market was further deepened through a series of EU decisions, how could the non-EU countries in the EEA say 'no', without the risk of economic loss?

The EU countries for their part, it must be remembered, had suggested the EEA as a 'stop-gap' solution. They wanted to avoid the decisionmaking indigestion that would follow with an even greater number of members, and they needed time to implement the 'I 992 ' Internal Market project. Now that this had been done, and with the four candidate countries knocking on the door for membership, enlargement was inevitable. Perhaps it was even desirable considering that the aspirants were comparatively wealthy. They were even likely to become net contributors to an ever more expensive and cash-strapped European Union.

Even if some of the four candidate countries, such as Austria, could have joined the EU simply through a vote of parliament, a referendum had become a political must, given the historical significance of joining, and following the hotly contested Danish and French referenda on the Treaty on European Union. This was especially so since the candidate countries, once admitted, were expected to ratify the Treaty as part of the deal. 
Austria went first. On the one hand, Austria needed the closest possible economic links with Germany. If the country remained outside, these links might suffer. Austria had also become an important hub for economic contacts between Western Europe and the transition countries in Central and Eastern Europe. As an EU member, Austria could strengthen this role.

On the other hand, the country's 1955 State Treaty, which had ended Allied occupation after World War II and restored Austrian sovereignty, obliged it to remain neutral. Was this compatible with the political union held out in the Treaty on European Union? To circumvent this problem the Austrians had their agreement with the EU state that, as an EU member, the country would not station foreign soldiers on its territory, take part in a new war or sign any military pact (even though the question of a later participation in a European defence pact was left open). In June 1994, despite an early strong showing by the 'anti' camp, Austrians voted two to one in favour of joining the EU.

The governments of all the four candidate countries - naturally enough eager to join as they had waged the accession negotiations and called referenda - were counting on a domino effect. The Finns, scheduled to vote in October, were expected to be swayed by the positive Austrian vote in the summer, and do likewise. Sweden was to follow in a vote in November, presumably impressed by a positive Finnish vote, whereupon the even more sceptical Norwegians could be assumed to toe the line a week later.

The calculation nearly worked. In October 1994 the Finns voted 57 per cent to 43 per cent in favour, reflecting a widespread fear of a possible renewed threat in the future from their neighbour to the east, but also their search for more extensive economic links with the EU area following the collapse of the considerable barter trade the Finns had enjoyed with the Soviet Union. Unemployment had risen rapidly over the past few years, and now affected nearly 20 per cent of the workforce. For a small, geographically peripheral and exposed country, it is often important to find protection and support in a continent's political centre - in this case the European Union - especially since NATO membership was not, yet, deemed possible. Opposition came mainly from the Communist Party that had earlier been closely aligned with that of the Soviet Union, and from many subsidised farmers who feared competition from more productive farms in the EU.

Sweden followed the Finnish example in November 1994, through a 52 per cent to 47 per cent vote in favour of joining the EU, thus ending a nearly forty-year-old tradition of shunning Community membership by 
invoking the latter's incompatibility with Swedish neutrality. The political establishment and business leaders had advocated membership, arguing that the economic crisis that had hit the country in I99I-92 would only deepen as companies would leave and foreign investment dry up if Sweden did not join (adding to the already, by Swedish standards, unheard-of I 3 per cent unemployment rate). The Social Democrats, back in power in September 1994 after a three-year absence, were seriously split over the issue, as many rank-and-file members feared an erosion of the Swedish welfare state under a supposedly more capitalistic Brussels regime. The Communist Party was against for the same reason, while environmentalists feared that similar concessions would have to be made in their particular field of interest. Even a number of conservatives were against, fearful that power would move from a democratic Stockholm to a bureaucratic Brussels.

City - in favour off membership - stood against countryside, which was mainly opposed to joining. The north, already peripheral in an oblong Sweden where two-thirds of the population live in the country's southern third, was more against, while the south was more in favour. Even Stockholmers, for now geographically in the centre, were less enthusiastic than the good people of Malmö who were facing a Copenhagen inside the EU across the Öresund straits. Following reports that snus, a form of chewing tobacco to which over a million Swedish men (and women) are addicted, would be banned once the country was in the EU, pro-EU sentiments took a deep dive. As it was, however, following EU assurances on this point, the 'yes' prevailed.

Would the Norwegians, who had said ' $n e i$ ' in the referendum in 1972 , follow? A joke made the rounds that the latest fashion was for nouveaux riches Norwegians to have a Mercedes and a Swedish chauffeur. Long the poor cousin of wealthy Sweden, Norway had now become Western Europe's biggest oil producer (surpassing the United Kingdom), with strong economic growth fuelled by that resource and low unemployment. Why should a country with such wealth join a European Union, with which it was already linked through a European Economic Area agreement, to whose budget it would be a major net contributor, and which promised to take power away from a - for many in the north already distant Oslo to an even more remote and impenetrable Brussels? The new name that the European Community had given itself, the European Union, evoked negative feelings with many Norwegians, against the historical background of involuntary 'unions', first with Denmark over 500 years ending in I8I4 and then with Sweden nearly ending in war in 1905. 
More security was scarcely needed than that provided by NATO, of which Norway was a founding member. Farmers were largely against, as they feared losing generous government support in exchange for much tougher competition from EU farmers. Fishermen were also subsidised. Why should they join an EU which pursued a 'Blue Europe' policy of Community sharing of fish resources - especially as they feared it would deplete stocks? Why risk the country's precious sovereignty over its other rich resources: oil, gas and light metals? For these assets as well as for its important shipping industry, the world - rather than just the EU - was Norway's main market. Finally, many women feared EU membership would undermine Norway's cradle-to-grave welfare system.

The Social Democratic government under Gro Harlem Bruntland, who had made the country's joining the EU a central political goal, found little response to its warning of an industrial exodus and economic hardship if the country said 'no'. This it did indeed do, on 20 November 1994, through a 52.4 per cent against joining the EU, to 47.6 per cent in favour.

The striking thing about the debates in all the four candidate countries was that they had centred on the self-interests of the particular nation. A 'what's-in-it-for-us?' attitude had settled in, whether it be farmers worried about EU competition or eager for CAP benefits; regions expecting money from the EU regional development fund or fearing to become even more peripheral from the Brussels horizon than they had been, say, from those of Oslo or Stockholm; or ordinary people worried about a company exodus in the event of non-membership, or of new trade barriers arising between, say, a Sweden within and a Norway without the EU (this was of course unrealistic, since it would risk being in breach of increasingly free trade GATT/WTO rules, apart from being unacceptable to the country inside - reduced trade, for example in Swedish regions bordering Norway, would hurt Swedish as much as Norwegian interests). ${ }^{4}$

A materialistic 'it's-your-money-we-want' attitude had also been prevalent on the part of certain EU countries during the membership negotiations, reflecting a departure from the more idealistic approach of earlier decades. For the poorer EU members it was a question of how much the new entrants would pay into the Cohesion Fund of regional aid mainly benefiting them, or how their agricultural produce would take the place of that which the candidate countries had previously imported, often at a lower price, from outside Europe. EU countries with a colonial past sought the same preferences for that nebulous and ever-growing group of nations gathered under the label of ACP countries 
(African, Caribbean and Pacific) already comprising over seventy states. ${ }^{5}$ However, there were none of the 'transition periods' that had been so frequent following the accessions of Greece, Portugal and Spain, the reason being that the new candidates had been part of the EEA (apart from being so competitive that no transition periods were needed).

On I January I995 the European Union welcomed Austria, Finland and Sweden as new members - while noting that, for a second time, the Norwegians had refused the offer of entry. The Twelve were now the Fifteen, with a new northern bias as two of the newcomers - Finland and Sweden - were on the EU's polar flank and a third - Austria - was at any rate not Mediterranean. They were also comparatively wealthy, thus contributing to an EU budget beyond which the organisation was statutorily obliged not to go, and which EU member governments were increasingly unwilling to augment as spending was increasingly demanded at home. The EU seemed to have fulfilled a new stage in its geographical expansion, now having as members all those wealthy Western European states that desired membership, while maintaining privileged trade relations with those that did not.

\section{An EU of fifteen; a NATO at peace?}

Another achievement was that Europe now seemed to have a panEuropean security structure which, though it was political rather than military, included the two transatlantic powers of the United States and Canada, whose presence, it was widely felt, was needed for future peace. The Conference on Security and Co-operation in Europe, the CSCE, had by $\mathrm{I} 995$ been transformed into a formal institution, the Organisation for Security and Co-operation in Europe, or the OSCE. As such it was endowed with a permanent, if small, secretariat and a consultative Parliamentary Assembly branch.

Meanwhile, NATO had its Partnership for Peace programme and was postponing the thorny issue of enlargement into Central and Eastern Europe. The Council of Europe entered a hectic period of enlargement culminating in February 1996 with the inclusion of Russia, to be followed in the coming years by virtually all remaining European states not yet members.

The ghosts of Stalin and Hitler seemed to be leaving the scene reluctantly, even though they ought perhaps to have been content with having so affected Europe and the world half a century after their deaths. Yet some traces remained. These included the Russian Kaliningrad enclave on the Baltic (the northern part of the former German East 
Prussia). It was now cut off from the rest of Russia but remained heavily armed and of continued strategic importance to Russia. There was also the redrawing of other national frontiers in the aftermath of World War II, setting the stage, at least potentially, for future conflicts among and within countries, in addition to those which the post World War I borders might supply.

However, the situation was far from problem-free for any of the organisations or countries involved. The European Union was immediately confronted with the request by numerous Central and East European countries to join, to which should be added those, of longer or shorter standing, of Cyprus (supported by Greece) and Turkey (opposed by Greece). How would EU finances, already strained, be able to cope with some, most or all of these countries as members? How would EU institutions cope, under strain from the already considerable divergences among member states, in what was still, essentially, an intergovernmental framework following, in most cases, the 'one-country-one-vote' principle?

Finally, how would the previously mentioned 'deepening' of EU integration fare, with so many more - and less economically developed newcomers? (Although this was one reason why at least some EU governments were so eagerly seeking enlargement in the first place.) Even if enlargement could be delayed, how could 'deepening' be achieved in the wake of the highly divisive process of ratifying the Treaty on European Union, which had brought to the surface deep-seated popular scepticism against further integration?

The OSCE was similarly hampered by continued reliance (as under the CSCE) on the unanimity principle before intervening to defuse a conflict. Its efforts, for instance, to contribute to a peaceful solution to the conflict in Chechnya in southern Russia - where separatists had been waging a bitter war of liberation against Russian troops since the autumn of I 994 - were largely fruitless.

NATO also faced many challenges. What role would it have after the disappearance of any threat from the East? On the other hand, many people felt NATO was needed as a sign of continued US-Canadian involvement in European security, and the disappearance of any such major institution would risk upsetting the status quo and leaving a dangerous void. No longer was anyone shouting 'Yankees, go home!' in Europe. On the contrary, most people were anxious that they stay in order to provide the stability that Europe had historically not seemed capable of mustering itself, and to guard against perceived threats from one or the other neighbour. In some NATO countries, such as Germany, 
the departing troops meant unemployment for thousands of civilians working on closed, or radically downsized, bases.

Meanwhile, on the other side of the Atlantic, voices were heard in favour of even more drastic reductions in military strength in Europe than those foreseen in the various international agreements. Why, many Americans argued, should the United States supply protection for Europe, when there was no longer any Soviet Union or Warsaw Pact to defend it against? Would the Old World never be able to stand on its own feet? For a younger generation of politicians from the western and south-western states, the future lay in Asia and along the Pacific Rim not in Europe as the now less dominant 'Eastern Establishment' from the county's eastern seaboard had thought.

Although France was eager to create a more independent European defence and security identity and therefore wished a less prominent NATO, it would in that event be left with a Germany - which though a close, democratic and peaceful EU partner - was perhaps nevertheless not to be fully trusted. If France thus was both attracted to and repelled by NATO, the matter appeared for some time to near a solution, at least temporarily, when the country in I 996 said it wanted to rejoin NATO's integrated military command structure (following its departure in I966 under President de Gaulle). Although continued French hesitations have since prevented formal reintegration, France apparently concluded that its own, and Europe's, interests were after all best served with continued North American involvement in European security.

One reason for the French change in attitude was doubtless the situation in Bosnia and Herzegovina. In spite of repeated joint European Union and United Nations initiatives, and a four-month ceasefire in early I995, the war in the region continued (with Croatian forces retaking from the Serbs several areas in Krajina and in western Bosnia and Herzegovina). It was only in October 1995 that a US-sponsored ceasefire could be proclaimed to give time for peace talks in Dayton, Ohio.

The so-called Dayton Agreements provided for a Bosnia-Herzegovinian state consisting of two entities: the Muslim-Croatian Federation (approximately $5 \mathrm{I}$ per cent of the territory, including the whole of Sarajevo) and the Serb Republic (Republica Srpska) with about 49 per cent. People indicted as war criminals would not be allowed to hold public office in either of the two entities. Bosnia-Herzegovina was to have a constitution and central institutions. Free elections were to be held within a specified period, and all refugees were to be allowed to return to their homes or if this was not possible - awarded proper compensation. The Agreements provided for the presence of 60,000 NATO troops (including 20,000 
from the United States) for one year to supervise the implementation of the Agreements. NATO, whose forces were deployed immediately after the signing of the Dayton Agreements, took over officially from the UN in Bosnia in December 1995.

This type of 'out-of-area' assignment was new to NATO and unforeseen in its 1949 Statute. The rationale - apart from the humanitarian aspect, which had by this time become an important NATO consideration - was that 'out-of-area' conflicts could easily spread to NATO-Europe and should therefore be seen as compatible with the organisation's mandate. (NATO had been involved since 1993 in the UN-mandated economic embargo against Yugoslavia - Serbia and Montenegro - and in the monitoring of a 'no-fly' rule for military aircraft in the civil war in the area.) Even though the joint endeavour operation in Bosnia and Herzegovina - initially involving some 60,000 troops and today far fewer - was costly, this was clearly an area where NATO was assisting European peace.

There remained the thorny issue of NATO enlargement. While it was clear that Russia would not be able to, or want to, go beyond its special co-operation agreement with NATO (within the Partnership for Peace framework) to full membership, numerous Central and East European countries wanted to join as early as possible, precisely to avoid any Russian threat in a more or less distant future. Yet how could they join without having Russia feel frightened or provoked, depending on how one interpreted that country's sentiments?

Furthermore, would NATO members be willing to live up to their commitments under the Washington Treaty of I949 if, say, a Baltic country or Poland were attacked from the east? Was not NATO going beyond its 'natural' defence perimeter, biting off more than it could chew if it did let some of these countries in? In addition, would NATO perhaps be brought into new territorial quarrels between members of the type it was already facing between Greece and Turkey?

On the other hand, did these candidate countries - democratic and constructive European partners - not have the same right as, say, a Denmark or a Luxembourg to seek collective defence of their freedom and national independence if they were ever threatened by an outside power? Besides, if a new status quo was not sought now, when there was no threat from the East, would that not in itself invite trouble, perhaps tempting an aggressor in the future?

The method applied by NATO members at the time was based on caution. Membership was held out as a prospect for the candidate countries, but the timetable was left vague, in the hope that time would 
make things clearer. Moscow's reaction to any overture was carefully registered - especially in Washington, which had the largest say. Washington also had to take into account the opinions of various ethnic groups in the US which hailed from Central and Eastern European countries and which clamoured for NATO membership for their several countries of origin. When membership was at last offered to the Czech Republic, Hungary and Poland - with the other candidates left either in various antechambers or out in the cold - the joining date was, however, set early, as will be seen later.

\section{Enlargement of the Council of Europe}

The Council of Europe faced a similar dilemma. Founded in I949 to achieve European political co-operation (rather than integration), it had been largely overshadowed by the EEC-EC and EU in subsequent decades, concentrating mainly on its role as a guardian of democracy, human rights and the rule of law. ${ }^{6}$ This role had been easy whilst communism existed. With the new situation in Central and Eastern Europe, however, the political mission of the Council again came to the fore, signifying that certain human rights principles might have to be compromised in the larger interest of political inclusion.

At the same time, how could an organisation, which had staked so much of its reputation on its work on behalf of democracy and human rights, live with certain members in its midst who did not seem fully to meet these requirements? What impact beyond its moral one did an organisation like the Council really possess? If it sacrificed its principles, would its soul survive?

Alternatively, others argued, if it excluded countries rather than include them, would that not prevent a 'critical dialogue' necessary to encourage improvements in human rights and democracy? If exclusion took place, that might risk having adverse consequences for many in the country targeted, and indeed for Europe as a whole, since the country in question might turn away from Europe towards, say, fundamentalist regimes in the Middle East. Did not Europe need an 'agora' - a forum - where differences could be aired and ironed out, where faulty behaviour could be criticised, prejudices overcome and guidelines and general principles agreed on?

The process that followed, especially from I994 onwards, was largely dictated by geopolitical considerations and the concern for inclusion and dialogue. The first Council of Europe summit, held in October 1993 with the participation of almost all European heads of state or government, gave rise to the so-called Vienna Declaration. It stated that: 
'The Council of Europe is the pre-eminent European political institution capable of welcoming, on an equal footing and in permanent structures, the democracies of Europe freed from communist oppression. For that reason the accession of those countries to the Council of Europe is a central factor in the process of European construction based on [the] Organisation's values.' By 2000 the membership of the Council of Europe had grown to forty-one countries, and more were to join. ${ }^{7}$

Meanwhile, a pattern of political and economic development was becoming discernible in the eastern half of the continent. In the foremost group were countries like Poland, the Czech Republic, Estonia, Hungary and Slovakia. They had pursued economic reform with determination. Aided by their proximity to Western European markets, they were growing at 5 per cent per year or more - that is, faster than the majority of Western European countries. Institutions were being reformed and democracy was taking firm root.

In a second group of nations, economic, political and institutional reform was proceeding more slowly, resulting in slower economic growth. Countries like Albania, Bulgaria, Romania and the 'former Yugoslav Republic of Macedonia' - all of which had in addition been seriously affected by the international embargo against Yugoslavia were in this group, as were Latvia and Lithuania.

A third group of countries - such as Belarus, Ukraine and Russia seemed to experience the worst of both worlds: the relative, though ossified, stability of communism was no longer, but the fundamentals of a market economy were still missing. The contraction of output which had characterised all the countries in the region following the dismantling of the state economy and the collapse of 'East-East' regional trade seemed never to end. Yet it was generally regarded as a healthy prerequisite for subsequent growth in an emerging private sector. The social, political and legal framework which should have assured foreign investors was slow in the coming. Corruption, mafia-like criminal organisations exacting 'protection money' from foreign or domestic entrepreneurs; confused and often contradictory legislation in areas such as property rights, accounting, taxation and repatriation of profits; all contributed to inhibiting international and locally engendered investment.

Russia had to cope with a festering sore in her southern underbelly: Chechnya. There, a war that had raged on and off since I994 had taken some 30,000 lives among civilians, Chechen rebels and Russian troops. The effect on the Russian army and public was similar to the case of Afghanistan a decade earlier: a sapping of morale and a sense that the nation was sinking into a quagmire. When a fragile peace was reached in 
the summer of 1996, the international community - where general sympathy with the rebels' quest for national independence mingled with worries about the wider ramifications for Russia's territorial integrity drew a sigh of relief, though nobody knew for how long the arms would remain silent. ${ }^{8}$

The general trend in the region was, however, one of continuing integration into the world economy. The fastest growing economies were setting an example for the rest and, by their very growth, provided increased trade with the others. None had any real choice but to continue to move, though sometimes in fits and starts, toward 'more market'. Any other course would mean delay vis-à-vis neighbours and a loss of foreign investment and innovation. Being in the world's 'loop of knowledge' meant opening up, not closing, society to ideas from the outside. Thus the Zeitgeist of the I990s was fundamentally opposite to that of, say, the I930s, when most countries in the region had fallen prey to fascist or communist dictatorships, seen as more conducive to economic growth through 'national mobilisation' and state management or outright ownership.

If Western Europe, and the world, were on the whole accommodating in this process, it was in part for moral and in part for more pragmatic reasons. There was a desire to help peoples who had for so long been oppressed and deprived of the kind of prosperity that the rich nations had started to take for granted. Helping them would also assist democracy, and the latter would assist economic growth, trade, and regional peace and stability. A pan-European system of co-operation and longterm peace and stability might even come about, with an as yet undefined co-ordination among NATO, the OSCE, the European Union, the Council of Europe, the Western European Union and the United Nations.

\section{An unsettled Western Europe}

While these were the priorities of politicians and institutions, the business world thought primarily in terms of the comparative advantages of the region, in particular its low cost of labour. And this was becoming costly politically to the politicians in Western Europe, who for the reasons stated, wanted to help. When companies started to move production to the East - say, from France or Germany to Poland or to the Czech Republic - unemployment rose in the West, in particular among the unskilled in the labour force.

Only in part could this be offset by increased exports of, for example, machinery for new plants in the East - machinery which as likely as not 
would now come from, say, South-East Asia. And only over time would increased prosperity among, say, Polish or Czech workers give rise to trade volumes that could benefit wide sectors of West European economies.

The dilemma was how to reach 'from here to there'. Increased unemployment was becoming particularly expensive to Western European states with their elaborate and generous welfare systems. If unemployment benefits were almost as high as the salaries lost, then tax levels would have to be raised for those who still worked, and for the companies that remained. However, higher taxes would mean less disposable income, and hence less domestic demand, while higher taxes for companies would mean higher cost of production, and hence an even greater incentive to move the production to lower-cost parts of the world.

Annual growth already at this time needed to be at least 2.5 per cent only to halt, let alone reverse, an increase in unemployment. Many countries in Western Europe therefore felt compelled to reform and open up their domestic economies for both products and services to international competition (under pressure to do so also from the EU and the WTO in particular), or else risk entering a vicious circle where insufficient growth, and growing unemployment, would sap growth even more. The conviction was taking hold in many Western European countries that major elements of the welfare state, built up over decades, had to be trimmed down. The strikes and social unrest in France in the autumn of 1995 and 1996 were essentially about that - as was the fierce opposition in 1999 by EU farmers against any reform of the CAP under the European Commission's Agenda 2000 proposal (which sought to replace price support measures linked to production levels with direct aid payments decoupled from production and instead related to environmental goals).

Germany - which before its entry into the EMU in I 999 maintained a strong currency that held down inflation but also inhibited exports was faced with a debate about the Standort Deutschland, or the very future of German industry in Germany (as distinct from German industry abroad through multinationals). The German economic machine had become more ossified, conservative and inflexible, causing it to lose out in competitiveness to many other countries, including in the EU. The country's problems were accentuated by the unexpectedly difficult task of lifting the new Länder (the former East Germany) up to the levels of prosperity enjoyed by the rest of the country. ${ }^{9}$ Reasons for this included, on the one hand, a persistent difference in the work ethic and work efficiency between 'Ossies' and 'Wessies', where the former felt that the 
latter were not helping enough and the latter thought that they were already doing too much; and salary increases insisted upon by the powerful German trade unions that were so high as to scare away German and foreign investors, who could now just as easily go to Poland, the Czech Republic, Slovakia or further afield. ${ }^{\text {IO }}$

As Keynesian solutions became an unreachable option due to high indebtedness and the exigencies of the EMU, the political crisis also deepened for other reasons. At the time of 'easy' growth, in the I950s and I960s, say, the political Left typically argued in favour of a more generous welfare state, and whenever they came to power they expanded it a little more. All the political Right could do, when in power, was to halt or slow down the process but not reverse it, as this would have cost it the next election. From the oil crises in the I970s onwards this could only be done through increased government borrowing, leading by the mid I990s to a situation where even the political Left, when in power, started to have no other option than to reduce the welfare state.

A prime example is Sweden, where the Social Democrats, after three years in opposition, were voted back into power in 1994 on a promise to restore the traditional Swedish welfare state. However, once in power they immediately had to start pursuing the same kind of policies that a right-of-centre type of government would have conducted.

For the ordinary European citizen the situation had become more difficult to understand. Had half a century of building an egalitarian, generous society been in vain? Where was the wealth of yesterday? Where were left and right in politics? The only consolation was perhaps that under a left-of-centre government the cuts might come later and affect fewer areas than under a right-of-centre one. But, if they came later, might not the country's finances suffer even further in the meantime, making eventual cuts even harsher? Was that post-war, unwritten social contract between the governing and the governed - by which the citizens had submitted to the rigours of economic change in exchange for social security and other, normally better paid, jobs - now coming undone? Where were the jobs anyway, and could one be sure any longer about the social protection part of the contract? There was less certainty for everyone, including in public service, to keep their job in the future, as companies scaled down their workforce to regain competitiveness. If 'globalisation', free trade and the economic development of Central and Eastern Europe were at fault, then the jobs of many people still depended on these very phenomena, in the sense that they gave rise to employment in the export sector and in growing multinational companies, as well as in commerce where more could be sold due to lower prices for imported goods. ${ }^{\text {II }}$ 
Such were the thoughts of millions of people in Western Europe. Their anxiety was exacerbated by corruption scandals, especially where public money was concerned, but also in the private sector through insider deals and excessive pay-offs and 'parachute' deals (sometimes kept secret) for executives. The goal was the welfare state. It had come, and now it seemed it was going again. Why? What values were there except money? But money can, in the final analysis, never be happiness itself, only a means thereto. God had been present during centuries of privation, but it seemed He had become more distant, as memories of dictatorships and oppressions started to fade, and recollections of material hardship with them.

Might the European ideal take the place of nationalism, the way it had in continental Europe in the first few years after World War II? But with memories of the war becoming increasingly distant - in spite of the fiftieth anniversary of D-Day, VE-day and the end of the war - that enthusiasm had been hard to rekindle in new generations who had had no direct experience of the horrors of war.

More importantly, as the stages of integration had been passed one after the other, Europe had become more prosaic than visionary. Europe had become a matter of milk quotas, regional aid, EU directives and intermittent squabbles. The Maastricht Treaty had brought home not only the bureaucratic dimension of the European Union - as exemplified in the interminable sentences they contained on the interplay among EU institutions - but also, in the minds of many, that a European superstructure was nearing completion and might indeed mean a loss of one's national identification.

Nationalism had been partly discredited. One variety of nationalism was still comme il faut, which found its expression in football matches, whether it was France or England who played, or, at subnational level, Bayern München or Real Madrid. However, that other brand, which maintained that one nation was intrinsically superior to another, or needed to crush another to show that superiority, was fortunately out of fashion. In that respect, happily, most European relations had come a long way from past centuries and the first half of the twentieth century.

There still was a belief in democracy. But democracy, for all its qualities, was still, in the famous words of Churchill, the 'worst form of government excepting all the others'. Especially in times of peace and prosperity, when it was not threatened, democracy could grow 'tired'. Nepotism, favouritism and greed could creep in. Vigilance over its functioning could become more relaxed. Every type of political system carried the seeds of its own destruction, and democracy was, alas, no 
exception. For democracy to survive, each and every generation must defend it as its most precious legacy, yet paradoxically the generations which most benefited from it saw the least reason to defend it.

The West may have cried victory after the demise of communism in I99I-92, but that did not mean it would remain invulnerable to decay from within. For instance, democracy vitally depended on a free and independent media, but the media could be bought up by powerful economic interests, to such an extent that they all conveyed the same message, thus anaesthetising a public opinion that needed diversity of opinion to preserve its most precious quality, common sense.

The market economy implied competition, which forced everybody to be on their toes and produce quality work in all walks of life, thereby raising overall wealth. Yet even competition in a market economy could, it was now realised, be reduced by mergers and cartels, the only possible salvation being that big conglomerates often collapsed under their own weight, in what the American economist Joseph Schumpeter had called 'creative destruction'. If competition became so harsh that a majority of the population were left outside the economic system, while a minority would have to work so hard to stay on top as to lose their humanism, then the market economy and the democracy that normally accompany it might themselves be in danger.

To many Europeans in the mid-I990s, the United States was in such a danger. On the one hand, they looked in envy at the low American unemployment level - half that of the European Union - and a net gain of some 38 million jobs since 1973, against the EU's zero. On the other hand, Europeans did not want millions of people abandoned by society the way they at least perceived the situation to be in the Harlems and the Wattses of the United States. However, if Europe did not bring down unemployment more and did not grow faster economically, would its weakened public finances not eventually lead to such a situation anyway?

\section{An uncertain world}

Such, then, was the overall situation in Western Europe by the mid I990s, as the ghosts of Hitler and Stalin bid a last farewell, hovering over the bulldozers tearing down the last remnants of the Berlin Wall. A profound feeling of uncertainty about the future reigned. It was a feeling that something was needed beyond materialism - even as material needs became more difficult to satisfy, especially when individuals compared themselves to the very rich and the very famous appearing on the screen and on television. 
Central and Eastern Europe were trying to reach the material level of the West. However, even as they did, they too were realising that Western materialism was somehow hollow. People who under communism had nurtured a dream of freedom and prosperity of course welcomed it when it came. Yet past solidarity with equally oppressed neighbours and friends had disappeared, as competition for jobs became increasingly harsh, and as materialism started to replace the more immaterial values which communism had come to engender; there was no longer any guarantee of a job for life nor of a position and status in society.

A new generation was growing up, desperately depending on their parents for material support long into late youth. That it was more moralistic and less spoilt than the previous one - that of the permissive I960s - was clear, as the menace of AIDS and a largely closed labour market loomed large. No longer was there any room for revolutionary visions of the youth of I968, as everybody tried somehow to find a slot in the existing system. But then again, not everybody was trying. Many youths with no or little schooling had largely 'opted out' of that system, as hope of finding a job was becoming slimmer with every passing year of inactivity, dwindling along with the capacity and desire to meet the challenges involved.

If the young had perhaps become more moral than their parents under the threat of AIDS, was the visual onslaught of television and video leaving them sufficiently literate to argue in the subtle way that democracy would seem to require in order to prosper? How would dialogue survive in the era of television and Gameboy?

The picture of a confused Europe in the mid-r990s drawn up here is, of course, in many respects an oversimplification. Millions of Europeans tightened their belts and were still happy. Football stadiums were filled with excited crowds, and beaches were filled with summer tourists. Many still had secure jobs, took only a scant interest in politics and perhaps did not know what, say, the Uruguay Round or the WTO stood for.

A country like Switzerland was rumoured to be unhappy and searching for its identity as it celebrated its 70oth anniversary in I991. However, with a low unemployment rate it did not seem too perturbed, even though its male population took to the mountains each year to practise defence against an enemy that no-one could really identify. Luxembourg had equally low unemployment and high growth, and questioned neither its role as a loyal EU member nor its banking secrecy laws, which so irritated many of its EU neighbours. Norway was in a similar situation and prided itself on being a good European without being an EU member. Many a Central and East European country relished its 
new-found freedom from oppression, with people suddenly able to afford a car and a holiday by the seaside.

Again on the joyful side, there was the major relief from the immediate nuclear threat, as masses of tactical weapons and intermediate-range nuclear missiles were being scrapped on all sides, and as even strategic weaponry was being reduced by most nuclear powers. Europe could 'breathe' for the first time since the early I950s, a palpable sign of which was that the German 'Easter Marches', which during the intermediaterange missile crisis of the mid-I980s had gathered up to half a million people, now mobilised far fewer, as worthy objects of protest were more difficult to find.

Presumably for the Germans, as for Europeans in general, the vision of war had become less that of a nuclear Armaggedon and more limited in scope - of the former-Yugoslavia type. It had also become messier, as in that region - or for that matter in Somalia, Burundi, Rwanda or SriLanka - it was not quite clear who was fighting whom for what purpose, and hence who was right and who was wrong. There was surely as much violence to deplore as during the Vietnam War, but its complexity was such that, unlike the I960s, there could be no rallying cry all over Europe to demonstrate on behalf of any one particular side (with the possible exception of the Bosnians during the siege of Sarajevo). Besides, the 'establishment' seemed to have the same views as the young in all these conflicts, making it difficult to present any stand of the young as, simultaneously, a revolt against their parents, as in the Vietnam days.

In conclusion, Europe in the mid-r990s had become more uncertain about itself and about its role in the world. The old, tired East-West confrontation was gone, and the resulting vacuum posed new challenges for countries and institutions such as NATO and the European Union. New technologies waged a head-on assault on economies, closing many traditional ways of doing things while opening up many new vistas for countries and individuals ready to embrace them. International economic competition intensified, with no country or region able to opt out. It is to Europe's responses to these challenges that we shall now turn.

\section{Notes}

I From Shakespeare's 'Sonnet 34'.

2 The START II Treaty was ratified by the US Senate, but not by the Russian Duma. It was superseded by the 2002 Treaty of Moscow.

3 The Schengen Agreement by 2002 covered fifteen European states: thirteen of the fifteen EU member states (that is all except the United Kingdom and Ireland) and two non-EU countries, Norway and Iceland. The latter have to 
respect all Schengen provisions without having any say in their shaping. Sweden, Finland and Denmark insisted that Norway and Iceland be allowed to participate, since all the five Nordic countries abolished mutual passport controls already in 1957.

4 A very complete analysis of the Austrian, Finnish, Swedish and Norwegian referenda is given in Luif (I995, Ch. I3).

5 In I963 eighteen countries signed the Yaoundé Convention with the European Economic Community to promote development co-operation. The Yaoundé Convention was followed by the signature by seventy countries of the Lomé Convention in I975. The Lomé Convention has been followed by Lomé II, III and IV, which latter expired in 2000. In the meantime over seventy ACP (African, Caribbean and Pacific) countries enjoy privileged trade and assistance status with the EU and have concluded a new convention, the Cotonou Agreement, which signifies a reorientation of EU development co-operation policies in the direction of a greater emphasis on democratisation and poverty reduction.

6 The Council of Europe in Strasbourg, founded in I949, is an intergovernmental organisation working for 'greater unity' between its forty-four member states 'for the purpose of safeguarding and realising the ideals and principles which are their common heritage and facilitating their economic and social progress'. The Committee of Ministers (composed of the Ministers of Foreign Affairs or their Permanent Representatives) is the Council's decision-making body. The Parliamentary Assembly is the organisation's deliberative organ, composed of delegations from national parliaments. A Congress of Local and Regional Authorities of Europe is a consultative body representing local and regional authorities. A particularly well-known part of the Council of Europe is the European Court of Human Rights, which bases its judgements on the European Convention on Human Rights and Fundamental Freedoms.

7 Croft, Redmond, Wyn Rees and Webber (I999, Ch. 6) see a 'mix of idealism and instrumentalism' in the attitudes of new and aspiring members to the Council of Europe. Membership is seen by some as a 'return to Europe', following the long separation from it under communism (especially in Central Europe and the Baltic states) - a 'symbolic acceptance of Europeanness'. In addition, 'membership of the Council of Europe satisfies an essential precondition of membership laid down by both the EU and NATO'. The authors conclude that 'the Council of Europe has been challenged in some new fundamental way by the most recent process of [its] enlargement'. While welcoming the organisation's 'proactive' stance on democracy and human rights and its suspension of 'recalcitrant states' such as Belarus, they wonder 'whether such a defence can be sustained in the face of democratic backsliding elsewhere', that is, in geopolitically more strategic countries. This underlines the Council's dual nature, some would say dilemma, as an intergovernmental, i.e. political, organisation and one based on fundamental, i.e. non-political, human values. 
8 In the event, hostilities were to break out again in the autumn of I999. In the war, the Chechnyan capital of Grozny was levelled to the ground, amid massive carnage among the civilian population.

9 Total transfers to the new Länder since unification in I 990 until 2002 were estimated at $€ 660$ million (DMr.3 billion). (Source: 'Sozialismus.de: Deutsche Subventionsmentalität und Bequemlichkeit', Neue Zürcher Zeitung, I-2 June 2002.)

Io In discussing the growing dissonance between 'East' and 'West' Germans, Knischewski (I996, pp I43-4) says the evolution has gone from the preunification state of 'united though divided' ('Spaltung in der Einheit') to the present-day 'divided by unity' ('Spaltung durch die Einheit') due to a psychological 'wall in the heads' ('Mauer in den Köpfen') replacing the Berlin Wall. 'Ossies' call the 'Wessies' 'Besserwessis' ('know-alls') and the 'Wessies' retort by calling the 'Ossies' 'Jammerossis' ('whinging Easterners').

I I Sassoon (I997, p 4) summed up the European Left's dilemma in these words:

Deprived of their pathfinders, the parties of the Left have adopted, more or less overtly, a defensive strategy. Its basic co-ordinates are an acceptance that market forces can be regulated but not eliminated; that such regulation must often be co-ordinated with other countries; that the growth of public spending should be curbed; that the welfare state can be defended but not extended; that privatisation may be unavoidable and, when it eradicates monopolies, desirable; that equality, though still appealing as a goal, may be tempered by the need to preserve incentives and competition; that the power of international financial institutions - and above all, of financial markets - may be contained, if at all, only by international agreement and not by unilateral state policies. 